\title{
An Introduction to Behaviourism, Innatism and Interactionism Theories of Language Acquisition: Literature Review
}

\section{Shivan Mawlood Hussein}

Department of English Language, College of Arts, Knowledge University, Erbil, Kurdistan Region Iraq

shivan.hussein@knu.edu.iq

\section{ARTICLE INFO}

\section{Article History:}

Received: $10 / 10 / 2019$

Accepted: $15 / 12 / 2019$

Published: Summer 2020

Keywords: Behaviourism, Innatism, Interactionism, Language Acquisition, Language learning.

Doi:

10.25212/Ifu.qzj.5.3.31

\begin{abstract}
There are many theories that have influence on the field of second language acquisition, and all of the theories have different principles and ideas. The knowledge about theories, methods, approaches, strategies and techniques is essential in order to have effective language classes. However, many of the instructors and teachers have lack of information about the language theories based on a survey which has been conducted in a social media poll. The poll consisted of two basic questions which were: 1- Are you familiar with the language theories? 2- Have you studied language theories in your academic studies? The number of teachers who answered the questions were 63 . The teachers are teaching from both the public sector and private sector. The result
\end{abstract}


demonstrated that 58 of the teachers were not familiar with the theories of language. Moreover, 60 of the teachers confirmed that they have not studied language theories in their studies. Therefore, this study aims to introduce the language theories including Behaviourism, Innatism and Interactionism in addition to principles, strengths and weak points of each theory. The current study concluded that teachers have to familiarize themselves with the theories of language acquisition through reading books, reading articles and participating in the teacher development courses in order to make their classes more effective and influential.

\section{INTRODUCTION}

There are many theories that have influence on the field of second language acquisition during last century and all of them have different principles and ideas. This study is pursuing to explain the history background of behaviorism, innatism and interactionism theory which are fundamental in language learning, and the views of each of the theories on learning language. However, traditional method of teaching is not sufficient in isolation in teaching and learning process. Teaching and learning process requires the recent teaching methods, including blended learning the flipped classroom which is considered as effective method to the existing digital age and 


\section{QALAAI ZANISTSCIENTIFIC JOURNAL \\ A Scientific Quarterly Refereed Journal Issued by Lebanese French University - Erbil, Kurdistan, Iraq \\ Vol. (5), No (3), Summer 2020 \\ ISSN 2518-6566 (Online) - ISSN 2518-6558 (Print)}

digital natives comparing to the traditional method of teaching (Hussein, Raouf \& Paulmony, 2019). Moreover, this study aims to identify and investigate the merits and demerits of the language theories in the field of second language acquisition. This study demonstrates the principles of behaviourism, innatism and interactionism with the evaluation of implementing each of the theories in language class which are familiar by all the educators and teachers.

\section{Behaviourism Theory}

There are numerous theories in terms of learning and acquiring language, while the most influential theory in the 1930s until 1950s was behaviourism. Behaviourism theory dominated the learning process in general and learning languages in specific until 1950s. Behaviourists believe that language is a mechanical process, they ignored the role of mind and consciousness in learning language. Behaviourism theory was established based on the idea of stimulus and response and it was brought from Pavlov's experiments on dogs. Behaviourists considered learning language and other forms of learning as a habit which could be gained or created through iterating and reinforcement of associations between stimuli and responses, whenever the association between stimuli and responses appears and is been created, a new habit will be created consequently (Ellis, 2003; Hadley, 1993; Johnson, 2004; Skinner, 2005).

\section{Principles of Behaviourism Theory}




\section{QALAAI ZANISTSCIENTIFIC JOURNAL \\ A Scientific Quarterly Refereed Journal Issued by Lebanese French University - Erbil, Kurdistan, Iraq \\ Vol. (5), No (3), Summer 2020 \\ ISSN 2518-6566 (Online) - ISSN 2518-6558 (Print)}

Behaviourism theory has numerous principles, the essential principle of behaviourism theory is general theory of learning which considered all languages (first language and second language) can be acquired in the same method based on the same principles. In addition, human beings have ability to learn everything in the similar method based on the equal principles (Johnson, 2004). According to behaviourists, there is no difference between the types of learning which means input could be received in order to produce output in language similar to other different types of learning. Behaviourists believed that verbal (spoken) behaviour and nonverbal behaviour are parallel in terms of learning. Furthermore, behaviourists indicated that human beings' leaning and animals' learning are comparable and similar (Skinner, 1957; Ellis, 2003).

According to the principles of behaviourism theory all types of learning are results of changes in behavior which were brought through experience. Behaviourists stated that learning can happen through manipulating the environment in order to experience the new behaviour, this means language is not a mental process while a mechanical process, as Skinner afforded to do in his experiments on animals (Politzer, 1961). In other words, when this idea is interpreted, it indicates that human beings' output is an evidence of getting input and also human beings produce output which is a copy of the input that they received, and this means learning is not a mental process.

All the kinds of learning are sourced from the changes in behaviors and can be obtained through experience. In other words, learning can happen through 


\section{QALAAI ZANISTSCIENTIFIC JOURNAL \\ A Scientific Quarterly Refereed Journal Issued by Lebanese French University - Erbil, Kurdistan, Iraq \\ Vol. (5), No (3), Summer 2020 \\ ISSN 2518-6566 (Online) - ISSN 2518-6558 (Print)}

controlling the environment. This is exactly what Skinner attempted to do in his animal experiments. One of the great concentrations of audiolingualism was the conviction that foreign language learning could be manipulated and induced by ensuring that the learners produce appropriate behaviour. If learning is equal to new behavior, it could be taught by inducing the correct behavior (Politzer, 1961).

Based on the behaviourism theory, learning can happen through making a connection between stimulus and response through repeat it again and again. This means children or adults can learn language(s) by creating new habits, then through practicing and training the connection between stimuli and responses language can be learned (Johnson, 2004). Language is a new set of habits, children can acquire and gain their first language (new habits) by repeating and imitating their parents that means learners can learn or acquire languages through repeating, mimicking or practicing the input that they receive from others (Ellis, 2003; Johnson, 2004; Skinner, 2005).

Behaviourists assumed that a child's mind was tabula rasa, human beings do not have any kind of innate competence or pre-programming system to improve their language when they are born. Based on the interpretation of this idea, behaviourists claims that all learning could be gained through experience, learning language is a mechanical process not a mental process, and the role of mental process is passive. The role of mind is neglected by behaviourists because the role of mind cannot not be observed in the learning process. Behaviourists only depend on the observable phenomena, action or behaviour (Ellis, 2003; Skinner 2005; Watson, 1924). 


\section{QALAAI ZANISTSCIENTIFIC JOURNAL \\ A Scientific Quarterly Refereed Journal Issued by Lebanese French University - Erbil, Kurdistan, Iraq \\ Vol. (5), No (3), Summer 2020 \\ ISSN 2518-6566 (Online) - ISSN 2518-6558 (Print)}

Positive reinforcement benefits learners to improve their language competence (output). Behaviourists stated that learners need to receive positive reinforcement when they imitate or repeat input correctly, in addition they have to receive punishment or negative reinforcement when they imitate or repeat input incorrectly (Ellis, 2003).

Based on the behaviourism theory, errors in the second or foreign language occur when old habits (the first language) interfere with input or new habits in the second or foreign languages. In other words, errors in a target language occur as a result of a negative transfer of the learners' first language habits, and errors needed to be corrected when they appear in the target language (output) (Johnson, 2004; Saville-Troike, 2006). Studies have confirmed that error correction has a positive effect on teaching and learning process (Ellis, 2009; Hussein \& Bostanci, 2020). However, the methods of correcting error are ignored in the behaviourism theory. Moreover, Paulmony \& Hussein (2019) stated that similarity in languages phonologically, syntactically, grammatically and asymmetrically of native language and target language has a positive effect on learning target language easily.

Behaviourists considered that learning language can be developed by analogy (emphasizes inductive through pattern - practice) instead of analysis which means learners can differentiate between the grammatical structures or patterns through similarities or differences between the patterns' examples that they receive. Furthermore, learners in analogy learning can predict and use similar patterns in similar situations with a different vocabulary. While in analysis learning, learners get 


\section{QALAAI ZANISTSCIENTIFIC JOURNAL \\ A Scientific Quarterly Refereed Journal Issued by Lebanese French University - Erbil, Kurdistan, Iraq \\ Vol. (5), No (3), Summer 2020 \\ ISSN 2518-6566 (Online) - ISSN 2518-6558 (Print)}

confused because they learn the rules of grammar before examples (Ellis, 1990; Brooks, 1960).

\section{Strengths of Behaviourism Theory}

Positive reinforcement encourages and motivates learners to learn effectively. Reinforcement is useful when it is used in a correct way. Positive reinforcement should be present when the correct answer is replied and it should be avoided when the wrong answer is replied. Reinforcement benefits the learning process (Skinner, 1957).

Another strength of behaviourism which can be counted as a useful aspect in the process of learning language is reactions. Reactions appear in humans' behaviour and they can be observed (Skinner, 1957). Unwanted or unnecessary reactions can be prevented and avoided in the process of learning language. In addition, most of the behaviourists focused on the orientation on positivism which is considered as one of the strengths in behaviourism theory (Skinner, 1953).

Imitation and repetition are partially useful for learning language because learners can learn and master their vocabularies, sounds, pronunciation through iterating and imitating, these techniques benefit learners to do more practice (Lightbown and Spada, 2006). In other words, imitation or repetition in pronunciation is still important and helpful especially to the early stages of learning languages, 


\section{QALAAI ZANISTSCIENTIFIC JOURNAL \\ A Scientific Quarterly Refereed Journal Issued by Lebanese French University - Erbil, Kurdistan, Iraq \\ Vol. (5), No (3), Summer 2020 \\ ISSN 2518-6566 (Online) - ISSN 2518-6558 (Print)}

through which learners become familiar with words and sounds in the second language.

Behaviourism theory focuses on observed behaviour (Skinner, 1957). One of the benefits of observed behaviour in behaviourism theory is that humans can easily make experiments on it. In addition, another strength of behaviourism is language learning procedure by mean of analogy rather than analysis; behaviourism focuses on inductive which means analysis involves "problem solving rather than habit formation" (Brooks, 1960).

\section{Criticism on Behaviourism Theory}

Language learning is not a simple process of imitation or repetition. Learning languages is a very complex process and effort should be done. Therefore, it is not as simple as only imitation process of a language. Human beings create novel sentences which were never learnt before. Chomsky's sentence "Colorless green ideas sleep furiously" is the best example for proving that statement (Saville-Troike, 2006).

According to behaviourism, language can be learnt like any other kind of learning because the principles of behaviourism lies in a general theory of learning (Johnson, 2004). This is one of the fundamental weak points of behaviourism because of two reasons: First, learning language and getting input in language are different from other kinds of learning and input. Second, it ignores the role of individualism in the process of learning. In other words, behaviourism theory cannot adequately explain and account second language acquisition (Ellis, 2003). 


\section{QALAAI ZANISTSCIENTIFIC JOURNAL \\ A Scientific Quarterly Refereed Journal Issued by Lebanese French University - Erbil, Kurdistan, Iraq \\ Vol. (5), No (3), Summer 2020 \\ ISSN 2518-6566 (Online) - ISSN 2518-6558 (Print)}

Behaviourism theory compares both the experiments of human and animals, for instance Pavlov's experiments on dogs and skinner's experiment on rat and pigeon. Behaviourists have ignored the role of mind in the process of learning, they believed that learning is a mechanical process which can happen through imitation and repetition. Furthermore, Behaviourism ignores mental processes and neglects the innate ability of humans (humans' competence of learning language) because of two reasons; First, mental process cannot be observed and behaviourists just explain visible actions or phenomena - in other words, behaviourism just observes visible behaviour (Skinner, 2005). Second, they counted language learning as a mechanical process therefore they ignored the role of mind or mental process. In addition, Chomsky stated that language cannot be defined by means of general theory because language is different and separate from other cognitive systems (Chomsky, 1959). It is true that human beings learn through imitation and repletion but is not the only source of learning language.

Language learning is more complex than learning through pattern-practices or structures of a language. Moreover, language learning is more sophisticated than learning structures or identifying structure of a pattern by perceiving similarity or difference with other patterns (discrimination and generalization) (Ellis, 2003). Based on the abovementioned statements, it could be concluded that focusing only on learning structure and grammatical rules in language classes is not an appropriate strategy to benefit learners to improve their communication competence. 


\section{QALAAI ZANISTSCIENTIFIC JOURNAL \\ A Scientific Quarterly Refereed Journal Issued by Lebanese French University - Erbil, Kurdistan, Iraq \\ Vol. (5), No (3), Summer 2020 \\ ISSN 2518-6566 (Online) - ISSN 2518-6558 (Print)}

Not all errors in the target languages are caused by language interference or mimicry as behaviourists believed. Some errors occur in the second language which are not caused by L1, only negative transfer cause some errors in target languages (Johnson, 2004).

\section{Pedagogical Aspect of Behaviorism Theory}

Imitation and repetition in pronunciation words and vocabularies could be helpful. Through imitating and repeating words with the correct pronunciation, learners will be able to control the words. Drills are still useful if they are followed by communication.

\section{Innatism Theory}

After the observable inadequacies of behaviourism theory and behaviourists belief in the field of second language acquisition, linguists pursued to find another theory to fill the gap that had been left by behaviourism. In 1959, Chomsky stated a new theory or idea that human beings have innate components of language or learning languages. Chomsky (1965) made a convincing idea and assumption which stated that children are born with innate competence and ability to learn specific language (language specific faculty) that Chomsky named as the language acquisition device (LAD), and universal grammar (UG) is a part of (LAD). The LAD means that the language is governed or controlled by a set of abstract principles which enables the child to create or set an infinite variety of sentences (Chomsky, 1965). 


\section{QALAAI ZANISTSCIENTIFIC JOURNAL \\ A Scientific Quarterly Refereed Journal Issued by Lebanese French University - Erbil, Kurdistan, Iraq \\ Vol. (5), No (3), Summer 2020 \\ ISSN 2518-6566 (Online) - ISSN 2518-6558 (Print)}

McLaughlin (1987) stated that Universal Grammar theory does not specify itself with second language acquisition while a number of second language researchers have implemented principles of Universal grammar to this field and they found sufficiently sophisticated explanations of the very intricate characteristics of interlanguages.

According to the Innatists learning language is a very complicated process, human beings cannot learn language through iterating and imitating without cognitive process because language learning is a very fast process cannot be done through imitation and repetition (Chomsky, 1965). Proponents of Universal Grammar believe that language ability is innate, which means human beings are born with a special capacity to create new rules or structures of the language system (Chomsky, 1965).

Innatists believe human beings are genetically designed and programmed to improve their language and linguistic systems and they need input to start the implementation of Language Acquisition Device. Children can produce and create unlimited new sentences that they did not acquire before which can never be produced by the poverty of the stimulus (Chomsky, 1965). Language is different from other kinds of learning because human beings have an innate competence to acquire and improve languages but they do not have the same competence to learn other types of learning (Chomsky, 1957).

\section{Monitor Theory (Monitor Model)}




\section{QALAAI ZANISTSCIENTIFIC JOURNAL \\ A Scientific Quarterly Refereed Journal Issued by Lebanese French University - Erbil, Kurdistan, Iraq \\ Vol. (5), No (3), Summer 2020 \\ ISSN 2518-6566 (Online) - ISSN 2518-6558 (Print)}

Monitor model is one of the approaches to second language acquisition (SLA) which has an internal focus. Monitor model was proposed by Stephen Krashen in 1978. Monitor model is one of the most influential approaches that has a great influence on SLA. According to Monitor Model, human beings (adults) can improve their language competence in second language acquisition through separate systems which are identified as: acquisition which means subconscious system, and learning that means conscious system. These two systems are connected in one way or another but the subconscious system appears to be more influential. Errors should not be corrected when they do not affect comprehensible input.

\section{Acquisition-Learning Hypothesis}

According to Krashen (1981), there are two different ways of getting language which are learning language (conscious process) and acquiring language (subconscious process). Acquiring language which is similar to a child's first language acquisition that means learners get input or acquire language but they do not know how they acquire language. In addition, acquisition goes beyond learners' level of awareness. In other words, acquiring language means learners do not focus on form and structure while they only focus on meaning. Therefore, teachers should not teach learners grammatical rules and structures while they should only provide input to acquire language. Krashen (1981) stated that human beings (children, adults and old people) have the ability to acquire or pick up languages (first language, second language) subconsciously, and language acquisition is with humans incessantly which 


\section{QALAAI ZANISTSCIENTIFIC JOURNAL \\ A Scientific Quarterly Refereed Journal Issued by Lebanese French University - Erbil, Kurdistan, Iraq \\ Vol. (5), No (3), Summer 2020 \\ ISSN 2518-6566 (Online) - ISSN 2518-6558 (Print)}

means the LAD never shuts off. Krashen (1981) indicated that learners do not need to learn grammatical if they acquired language, native speakers do not need grammatical structures to speak, they automatically use language correctly without thinking of rules. Krashen also demonstrated that acquisition is a spontaneous process, it does not need effort, it happens automatically. Acquisition means the learner's focus is on meaning. Acquisition is usually an informal process (Johnson, 2004; Krashen, 1981; Lightbown and Spada, 2006; Saville-Troike, 2006).

Learning language (conscious learning) means having conscious knowledge of the target language. In other words, the focus of learning language is on form and structure not meaning. Krashen (1981) believed that learning language is useful in controlling output for instance correcting errors in output. Krashen indicated that conscious knowledge (learned knowledge) cannot be converted to subconscious knowledge (acquired knowledge). Moreover, Krashen demonstrated that acquisition benefits learners in both fluency and accuracy while learning only benefits learners in accuracy (Johnson, 2004; Krashen, 1981; Lightbown and Spada, 2006; Saville-Troike, 2006).

\section{The Input Hypothesis}

Krashen (1981) stated that when learners understand the massage through listening or reading, language acquisition takes place and it is called comprehensible input. In addition, when learners get comprehensible input Language Acquisition Device starts working and it happens subconsciously. Krashen (1981) indicated that input (comprehensible input) is necessary and sufficient for acquiring language. On 


\section{QALAAI ZANISTSCIENTIFIC JOURNAL \\ A Scientific Quarterly Refereed Journal Issued by Lebanese French University - Erbil, Kurdistan, Iraq \\ Vol. (5), No (3), Summer 2020 \\ ISSN 2518-6566 (Online) - ISSN 2518-6558 (Print)}

the other hand, output (speaking and writing) does not help learners to acquire language because output is a result of comprehensible input. Comprehensible input means learners' focus is on meaning not form and comprehensible input takes place when learners understand the meaning of the message. Input needs to be at the level that could be understood by learners. Learners acquire language through comprehensible input when the input is $(i+1)$ which means input is slightly higher than learners' current level of competence. In contrast, learners do not acquire language when the input is pitched only an (i+0) which means there is nothing new to learn and also the input will not be useful when input is much higher than learners' current level of competence (i+2) or (i+3) (Hadley, 1993; Johnson, 2004; Krashen, 1981; Lightbown and Spada, 2006).

\section{The Monitor Hypothesis}

According to the monitor hypothesis, the acquired system is responsible for speaking and utterance which originates from the subconscious system. Learning knowledge (conscious system) is useful while it is practiced only for conscious uses such as a monitor, editor or for correcting errors in the output (speaking and writing). According to Krashen, a monitor hypothesis is used in three conditions: first, learners should have sufficient time to think. Second, learners' focus is on the form not meaning. Finally, when learners have enough background knowledge about rules of grammar for doing monitoring or editing (Johnson, 2004; Krashen, 1981; SavilleTroike, 2006). 


\section{QALAAI ZANISTSCIENTIFIC JOURNAL \\ A Scientific Quarterly Refereed Journal Issued by Lebanese French University - Erbil, Kurdistan, Iraq \\ Vol. (5), No (3), Summer 2020 \\ ISSN 2518-6566 (Online) - ISSN 2518-6558 (Print)}

\section{The Natural Order Hypothesis}

Human beings can learn the rules of language or grammatical structures in a predictable order (Saville-Troike, 2006). Krashen (1981) believed that there is a predictable order for learning structures, while it is not condition the order starts from simple to complex. Simple rules are not conditioned to be explained or taught first and the complex rules are explained later. Krashen (1981) stated that learners should learn the structures naturally or in a natural order. When learners acquire second language in a natural order, there must be a mechanism that processes input according to an innate, universal, and rule-governed system (Johnson, 2004).

\section{Affective Filter Hypothesis}

Affective filter refers to learners' emotion. According to Krashen (1981), there is an imaginary filter in language acquisition. When the affective filter is high, comprehensible input is low because the affective filter blocks out comprehensible input. When the affective filter is high learners would have less self-confidence, low motivation and high anxiety. In contrast, when the Affective Filter is low, learners will have self-confidence, high motivation. High Affective Filter blocks out comprehensible input from reaching $L A D$ and in that case the input will not be comprehensible by learners. Johnson (2004) considered Affective Filter as "a mental block" which prevents learners to have comprehensible input. Affective filter prevents learner's mental process from using the comprehensible input which learners get or receive (Johnson, 2004; Saville-Troike, 2006; Lightbown and Spada, 2006). 


\section{QALAAI ZANISTSCIENTIFIC JOURNAL \\ A Scientific Quarterly Refereed Journal Issued by Lebanese French University - Erbil, Kurdistan, Iraq \\ Vol. (5), No (3), Summer 2020 \\ ISSN 2518-6566 (Online) - ISSN 2518-6558 (Print)}

\section{Strength of Innatism}

According to Brown (2000) most of the English second language and English foreign language (ESL/EFL) teachers have taken benefits from Krashen's monitor hypothesis because it is easy to follow. In addition, ESL/EFL teachers can base their teaching methods on the Krashen's five hypotheses in language acquisition and language learning.

Krashen emphasized on the role of input (comprehensible input) in second language, in addition Krashen presents a convincing explanation of the complexity of language acquisition. Long (1983) stated that children whose parents are deaf or blind improve their language acquisition or competence later than other children because of the lack of comprehensible input that they receive from their parents.

Krashen natural approach of input considered as a watershed of changing teaching attitude, style, and approaches from teaching grammar to communication. In other words, natural input benefits teachers to focus on natural order of input rather than focusing on pre-selected linguistic input (Brown, 2000).

Krashen partially explained the importance of subconscious language acquisition and the influence of subconscious language acquisition on acquiring languages, he stated that language acquisition is informal while leaning language (conscious) is formal. In addition, Krashen stated that the success of informal process is in contrast to formal process in language acquisition (Krashen, 1981). 


\section{QALAAI ZANISTSCIENTIFIC JOURNAL \\ A Scientific Quarterly Refereed Journal Issued by Lebanese French University - Erbil, Kurdistan, Iraq \\ Vol. (5), No (3), Summer 2020 \\ ISSN 2518-6566 (Online) - ISSN 2518-6558 (Print)}

Krashen explained the role of subconscious acquisition in language acquisition and language classes. Language teachers need to focus on the subconscious instead of conscious direct teaching grammar. Krashen's Monitor Model and the idea of $(i+1)$ are useful for language acquisition classes. Teachers should provide students with input which is a little higher than students current level, not (i+2) or (i+3) and not to be equal to the students' current level (Johnson, 2004). Innatism theory verified the role of humans' competence to learn language. In addition, innatism theory identified the role of mind in learning languages (Saville-Troike, 2006).

\section{Criticism on Innatism Theory}

Krashen's view of necessary and sufficient has been criticized by interactionists who believe that input is necessary for acquiring language but not sufficient. Swain (1985) stated that comprehensible is necessary while language may also be acquired through output (speaking or writing) as well, French Immersion Programme is a convincing example for supporting this idea. Contrary to the Krashen's view, output may cause language acquisition because language acquisition can be noticed through the analysis of learners' output (Richards and Schmidt, 2002).

Krashen's view of non-interface theory cannot be proven. Krashen believes that learned knowledge (conscious knowledge) cannot be converted into acquired knowledge (subconscious knowledge) which means language cannot be acquired through conscious knowledge. On the other hand, contrary to this view, conscious knowledge sometimes is beneficial to acquire languages. Another weakness is the ambiguity of $(i+1)$, affective filter, learned knowledge, and acquired knowledge 


\section{QALAAI ZANISTSCIENTIFIC JOURNAL \\ A Scientific Quarterly Refereed Journal Issued by Lebanese French University - Erbil, Kurdistan, Iraq \\ Vol. (5), No (3), Summer 2020 \\ ISSN 2518-6566 (Online) - ISSN 2518-6558 (Print)}

cannot be measured or tested. Therefore, Krashen could not define or explain these notions clearly. Interactionists criticize Krashen because Krashen stated that second language acquisition is different from first language acquisition, and focusing on form is necessary for monitoring and editing output but not for acquiring language (Johnson, 2004).

Krashen stated that comprehensible input is responsible for acquiring languages. While, he did not explain the role of individual and environment clearly in acquiring comprehensible input. Krashen did not explain when the message (input) cannot be understood by learners, learners need to be criticized or the environment (Johnson, 2004).

\section{Interactionism Theory}

The supporters of interactionism emphasize on the social context of language development. Moreover, the interactionism theory focuses on the aspects of the relationships between those people who are trying to learn languages. There is a disagreement between the above mentioned views and the linguistic approaches which claim that language acquisition can be acquired by analyzing the learner's utterances, regardless to the person's cognitive development or social aspects of learners' life. (Richards and Schmidt, 2002). 


\section{QALAAI ZANISTSCIENTIFIC JOURNAL \\ A Scientific Quarterly Refereed Journal Issued by Lebanese French University - Erbil, Kurdistan, Iraq \\ Vol. (5), No (3), Summer 2020 \\ ISSN 2518-6566 (Online) - ISSN 2518-6558 (Print)}

Interactionists believe that language can be developed through both social and biological processes for instance children acquire language through communicating with parents or other people, their needs motivate them to interact which means through communication children are willing to produce words and sentences (output). Interactionists argue that when children are born, they have a powerful brain which gradually get mature and they have the ability to communicate. This process is slow but prompts them to acquire new understanding that they are more willing to share with others (Bates, 1993; Tomasello, 1990, Shaffer, et al., 2002).

\section{Principles of Interactionism Theory}

Interactionists concentrates on two main views:

1. The belief that language learning is "the Interaction Hypothesis".

2. The argument that language learning is "The Comprehension Output Hypothesis".

The "Interaction Hypothesis" reveals that language acquisition needs or takes great benefits from interaction, communication and specifically negotiation of meaning. This principle occurs when interlocutors try to defeat difficulties to communicate and convey the meaning. Interaction Hypothesis focuses on more input as well as useful and efficient feedback on the learner's output (Richards and Schmidt, 2002). Long (1989) and Pica (1987) examined oral interaction hypothesis, they concluded two significant points regarding second language acquisition which are: (1) Comprehensible input is essential for second language acquisition, and (2) output is 


\section{QALAAI ZANISTSCIENTIFIC JOURNAL \\ A Scientific Quarterly Refereed Journal Issued by Lebanese French University - Erbil, Kurdistan, Iraq \\ Vol. (5), No (3), Summer 2020 \\ ISSN 2518-6566 (Online) - ISSN 2518-6558 (Print)}

important in finding the gap and modifying the input. These two claims originated from Stephen Krashen and Evelyne Hatche's views.

Swain (1985) has a view on the comprehensible output hypothesis. Swain (1985) indicated that in order to acquire language successfully, the learner needs both comprehensible input and comprehensible output so that people can understand what the speaker means through his utterances. It is believed that when learners try to make sure that they are able to convey their messages (output), they will be in a better condition to consider the gap between their own utterances and what is produced by the proficient speakers.

\section{Strengths of Interactionism Theory}

According to the studies conducted by Long (1985) and Chaudron (1985a; 1988) modifying input is revealed to be helpful in comprehending tests in written and spoken form by frequency of speech, diminution of syntactic complexity, and increased redundancy.

\section{Weaknesses of Interactionism Theory}

The first weakness, interaction theory is difficult to be implemented in the real context of second language acquisition because second language learners have no chance to interact with native speakers in a second language acquisition context or classroom which means the frequency of communication and interaction is low, and learners can only communicate and interact in the classroom. The second limitation 


\section{QALAAI ZANISTSCIENTIFIC JOURNAL \\ A Scientific Quarterly Refereed Journal Issued by Lebanese French University - Erbil, Kurdistan, Iraq \\ Vol. (5), No (3), Summer 2020 \\ ISSN 2518-6566 (Online) - ISSN 2518-6558 (Print)}

of interaction theory is there is no confirmation to prove that language acquisition is improved by comprehension while interactional modifications improves comprehension (Long, 1981).

\section{Pedagogical Implications of Interactionism Theory}

The theories of language acquisition and learning include numerous methods, approaches, strategies, techniques and activities. The role of teachers and educators is how to understand the theories, methods, approaches, strategies, techniques and activities, and implement them in their classes. Teachers need to understand the effect of the techniques and activities, and measure which of them are effective and beneficial for the students. Instructors and teachers are required to use the strategies, techniques and activities which are appropriate to the students, not teachers think is useful. Therefore, the following are findings and views of some scholars about using theories, methods, approaches, strategies, techniques and activities in the language classes.

According to Ellis (1999), in a class where the communication is controlled by learners, negotiation is significantly richer than negotiation in a class where teachers controlled discussion and communication. In other words, the tasks that the students involve in, the participation changes to an activity-centered situation. As a result, Van Lier (1988) believes that learners can control communication or a topic oriented classroom in different ways such as interview, conversation, and talking circle. The teacher starts, learners answer, the teacher provides feedback aiming the students control the discourse and communication in the class (Ellis, 1999). Therefore, based 


\section{QALAAI ZANISTSCIENTIFIC JOURNAL \\ A Scientific Quarterly Refereed Journal Issued by Lebanese French University - Erbil, Kurdistan, Iraq \\ Vol. (5), No (3), Summer 2020 \\ ISSN 2518-6566 (Online) - ISSN 2518-6558 (Print)}

on what Johnson (1995) states, in order to obtain the most efficient acquisition in a classroom, there should be a context which motivates learners to participate. The context should be in a form that learners have chances to express themselves and convey their message.

According to Pica (1987) interactional learning is based on the atmosphere in which the learners and interlocutors actively negotiate. In such a context, the learner is an equal discusser in which the discourse contains one-way grammatical utterances from learner to interlocutor. Pica (1987) believed that activities through which information is shared have more effect on learner's interactional, negotiation of meaning, and modification of structures compared with the activities that encourage the learners to involve themselves.

There are various kinds of activities and tasks to expose language learners to improve their input. For example, intensive reading through which the language learners are asked to read different texts to acquire more comprehensible input additionally to the former acquired words and knowledge of grammatical structures. Teaching other subjects such as master science or math, etc. help learners to get intensive comprehensible input.

Meaning focused reading is another way to promote input (comprehensible input). Through this kind of reading that seems fun, learners have to unscramble the sentences of a short story. Therefore, the learners are not focused on improving their vocabulary or grammar while they focus on the content and meaning of the whole story. In addition, there are activities which increase interaction and students' 


\section{QALAAI ZANISTSCIENTIFIC JOURNAL \\ A Scientific Quarterly Refereed Journal Issued by Lebanese French University - Erbil, Kurdistan, Iraq \\ Vol. (5), No (3), Summer 2020 \\ ISSN 2518-6566 (Online) - ISSN 2518-6558 (Print)}

motivation including activities to ask students to find one another's mistakes in both speaking and reading text.

Listening materials and audio-visual materials including cartoons, movies, animations, news, and song are very efficient in language acquisition and learning and students hardly forget them, especially when the materials are funny and interesting. Through the above-mentioned activities, learners can improve their listening skills and some sub-skills like grammar, vocabulary, pronunciation, language function etc. Listening practice which is considered as one of the sources of input can be implemented in different ways. In some of the listening activities learners are required to read only the questions before listening to the material in order to focus on the answers of the questions rather than comprehending the whole text. Moreover, the students can explain what the speakers said after the teacher pauses at the end of each part. This way the students get input and learn new word and structures as well.

\section{Conclusion and Recommendation}

In conclusion, all the language theories have merits and demerits in language acquisition and learning. Instructors, teachers and educators are the most influential characters who decide how to follow the theories and which theory is appropriate in 


\section{QALAAI ZANISTSCIENTIFIC JOURNAL \\ A Scientific Quarterly Refereed Journal Issued by Lebanese French University - Erbil, Kurdistan, Iraq \\ Vol. (5), No (3), Summer 2020 \\ ISSN 2518-6566 (Online) - ISSN 2518-6558 (Print)}

their classes. Teachers need to provide a motivated and encouraged environment through which all the learners willing participate in the activities and classroom discussion.

Teachers have to familiarize themselves with the theories of language acquisition through reading books and participating in the teacher development course in order to make their classes more effective and influential.

In terms of theories, based on the strengths and weak points, it could be concluded that interactionism and innatism theories are more influential compared with behaviourism theory in the field of second language acquisition. Moreover, the interactionism theory seems to be more effective in the second and foreign language classes through identifying the problems of language acquisition and providing proper solutions. However, interactionism theory is not sufficient to provide a proper method, approaches, strategies and techniques to acquire languages. Second language acquisition is a very complex process. Therefore, through implementing all the effective aspects of all theories learners can acquire languages better and learning can happen more effectively. The Interaction between conscious and subconscious processes benefits the process of second language acquisition to be developed because no one of learning and acquisition can stand alone to improve learners' knowledge in the second language acquisition.

\section{REFERENCES:}




\section{QALAAI ZANISTSCIENTIFIC JOURNAL \\ A Scientific Quarterly Refereed Journal Issued by Lebanese French University - Erbil, Kurdistan, Iraq \\ Vol. (5), No (3), Summer 2020 \\ ISSN 2518-6566 (Online) - ISSN 2518-6558 (Print)}

Bates, E. (1993). Comprehension and production in early language development: Comments on Savage-Rumbaugh et al. Monographs of the Society for Research in Child Development, Serial No. 233, Vol. 58, Nos. 3-4,222-242.

Blau, E (1982). The effect of syntax on readability for ESL students in Puerto Rico. TESOL Quarterly 16 (4): 517-28.

Brooks, N. (1960). Language and language learning. New York.

Brown, H. D. (2000). Principles of language learning and teaching. New York: Longman.

Chaudron, C. (1985a). Intake: on models and methods for discovering learners' processing of input. Studies in Second Language Acquisition 7: 1-14 Chaudron, C 1985b Comprehension, comprehensibility, and learning in the second language classroom. Studies in Second Language Acquisition 7: 216-32.

Chaudron, C. (1988). Second language classrooms: research on teaching and learning. Cambridge University Press.

Chomsky, N. (1959). Review of Verbal behavior by B F Skinner. Language 35: 26-58.

Chomsky, N. (1957). Syntactic Structures, the Hauge, Mouton.

Chomsky, N. (1965). Aspect of the theory of syntax. Cambridge, mass: MIT press.

Ellis, R (1990). Instructed second language acquisition. Oxford: Blackwell.

Ellis, R. (1999). Learning a Second Language through Interaction. Amsterdam: John Benjamins.

Ellis, R. (2003). Second language acquisition. Oxford New York: Oxford university press.

Ellis, R. (2009). Corrective feedback and teacher development. L2 Journal, 1(1). 


\section{QALAAI ZANISTSCIENTIFIC JOURNAL \\ A Scientific Quarterly Refereed Journal Issued by Lebanese French University - Erbil, Kurdistan, Iraq \\ Vol. (5), No (3), Summer 2020 \\ ISSN 2518-6566 (Online) - ISSN 2518-6558 (Print)}

Hadley, A. O. (1993). Teaching language in context (2nd ed). Boston, Mass: Heinle, T. Heinle Publishers.

Hussein, S. M., \& Bostanci, H. B. (2020). The Correlation between Error Correction and Grammar Accuracy in Second Language Writing. International Journal of Psychosocial Rehabilitation, 24(05).

Hussein, S. M., Hunar M. Hussein M. Raouf, \& Robinson Paulmony. (2019). The Effect of the Flipped Classroom on Learning Process: A Literature Review. Restaurant Business, 118(11), 42-58. Retrieved from https://journals.eduindex.org/index.php/rb/article/view/9932.

Johnson, M. (2004). A philosophy of second language acquisition. Yale university press: Mary Jan Peluso.

Johnson, K. (1995). Understanding communication in second language classrooms. Cambridge: Cambridge University Press.

Krashen, S. D. (1981). Second language acquisition and second language learning. pergamon press.

Krashen, S. D. (1982). Principles and practice in second language acquisition. Oxford: Pergamon.

Lightbown P. M. and Spada, N. (2006). How languages are learned (3rd ed). oxford New York: oxford university press.

Long, M. H. (1981). Input, interaction and second language acquisition. In Winitz, $\mathrm{H}$. (ed.), Native language and foreign language acquisition. Annals of the New York Academy of Sciences 379, 259-78.

Long, M. H. (1983). Native speaker/non-native speaker conversation and the negotiation of comprehensible input. Applied Linguistics 4: 126-41. 


\section{QALAAI ZANISTSCIENTIFIC JOURNAL \\ A Scientific Quarterly Refereed Journal Issued by Lebanese French University - Erbil, Kurdistan, Iraq \\ Vol. (5), No (3), Summer 2020 \\ ISSN 2518-6566 (Online) - ISSN 2518-6558 (Print)}

Long, M. H. (1985). A role for Instruction in Second Language Acquisition: Task-Based Language Teaching. In K. Hystelstam, \& M. Pienemann (Eds.), Modeling and accessing Second Language Acquisition. Cleverdon, UK: Multilingual Matters.

Long, M. H. (1989). Task, Group and Task-Group Interaction, Hawaii university. ESL.8.1-26.

McLaughlin, Barry. (1987). Second Language Acquisition in childhood. Hillsadale, NY: Lawrence Erlbaum, 1978.Second -language learning. London: Edward Arnold.

Pica, T. (1987). Second-language acquisition, social interaction, and the classroom. Applied Linguistics, 8, 3 - 21.

Robinson Paulmony \& Hussein, S. M. (2019). Phonological and Grammatical Similarities between English and Kurdish Language: Why English Learning is Easier for Kurdish. Universal Journal of Educational Research. 7. 2705-2709. 10.13189/ujer.2019.071218.

Politzer, R. (1961). Teaching French: An Introduction to Applied Linguistic. Boston: Ginn.

Richards, J.C. and Schmidt, R. (2002) Longman Dictionary of Language Teaching \& Applied Linguistics (3rd edition). Essex: Pearson Education Limited.

Saville-Troike, M. (2006). Introducing second language acquisition. New York: Cambridge university press.

Shaffer, D. R., Wood, E., \& Willoughby, T. (2002). Developmental psychology: Childhood and adolescence (First Canadian Edition). Scarborough, Ont: Nelson/Thomson Canada Ltd.

Skinner, B. F. (1953). Science and Human Behavior. New York: Macmillan.

Skinner, B. F. (1957). Verbal behavior. New York: Appleton Century Crofts. 


\section{QALAAI ZANISTSCIENTIFIC JOURNAL \\ A Scientific Quarterly Refereed Journal Issued by Lebanese French University - Erbil, Kurdistan, Iraq \\ Vol. (5), No (3), Summer 2020 \\ ISSN 2518-6566 (Online) - ISSN 2518-6558 (Print)}

Skinner, B. F. (2005). Science and human behavior. Pearson Education.

Swain, M. (1985). Communicative competence. Some roles of comprehensible input and comprehensible output in its development. In Gass and Madden (1995).

Tomasello, M. (1990) Cultural transmission in the tool use and communicatory signaling of chimpanzees? In 'Language' and intelligence in monkeys and apes: comparative developmental perspectives (eds S. T. Parker \& K. R. Gibson), pp. 274311. New York, NY: Cambridge University Press.

Van Lier, L. (1988). The Classroom and the Language Learner. London: Longman.

Watson, J. B. (1924). Behaviorism. New York: Norton.

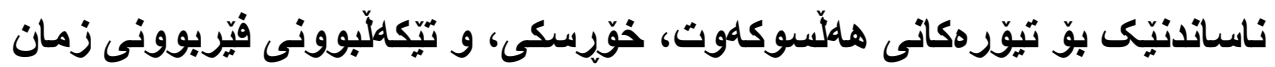

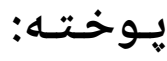

كوّمهلّيّك تيوّر ههن كه كاريكهريان ههيه لهسهر بوارى وهرگرتنى زمانى دووهم، ههوو ئهم تيوّرانه بنهما و بيروّكهى جياوازيان ههيه. زانيارى دهربارهى تيوّر، ريّجِكه، شيواز، ستراتيجى، و تهكنيكهكان يِيّويستن بوّ ههبوونى يوّليّكى فيّركردنى زمان بهشيّوهيهكى كاريكهر. سهرهراى ئهمه، ماموّستايان زانياريهكى كهميان ههيه لهسهر تيوّرهكانى زمان به يشت بهستن به رِإيرسيهك كه له سوّشيال ميديا ئهنجام درا. رإيرسييهكه له دوو يرسيار يِيك هاتبوو كه بريتى بوون له: 1ـ ئاشنايت (زانياريت ههيه) به تيوّرهكانى فيّربوونى زمان؟ 2. تيوّرهكانى فيّربوونى زمانت خويندووه له كاتى خويِندنى ئهكاديمى؟ زمارهى ماموّستايانى بهشداربوو 63 ماموّستا بوو. ماموّستاكان له كهرتى گشتى و كهرتى تايبهت 


\section{QALAAI ZANISTSCIENTIFIC JOURNAL}

A Scientific Quarterly Refereed Journal Issued by Lebanese French University - Erbil, Kurdistan, Iraq

Vol. (5), No (3), Summer 2020

ISSN 2518-6566 (Online) - ISSN 2518-6558 (Print)

وانهيان دهووتهوه. ئهنجامهكه دهريخست 58 ماموّستا ئاشنا نين به تيوّرهكانى فيّربوونى زمان.

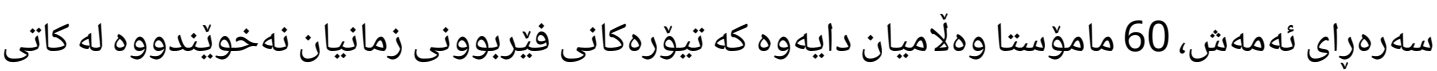

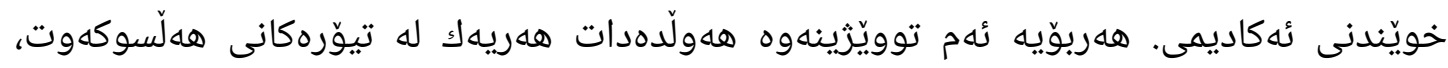

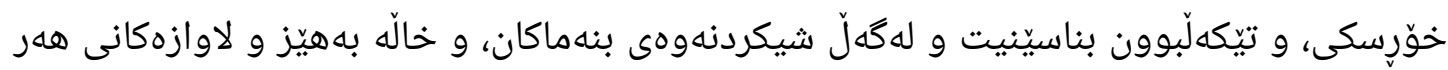
تيوّريّك. ئهم توويَزينهوه گهيشته ئهو دهرئهنجامهى كه ماموّستا يِيّويسته خوّى ئاشنا بكات به تيوَرهكانى فيّربوونى زمان له ميانهى خويِندنهوهى يهرتووك، تويّزينهوه، و بهشداريكردن له خولى كهشه سهندنى ماموّستايان تاوهكو بتوانيّت وانهكانى كاريكهر بكات.

\section{مقدمة في النظريات السلوكية والفطرية والتفاعلية لاكتساب اللغة}

هناك العديد من النظريات التي لها تأثير على مجال اكتساب اللغة الثانية. كل النظريات لها مبادئ وأفكار مختلفة. المعرفة بالنظريات والأساليب والنهج والاستراتيجيات والتقنيات ضرورية من أجل الحصول على فصول لغة فعالة. ومع ذلك ، فإن العديد من المعلمين والمدرسين يفتقرون إلى المعلومات حول

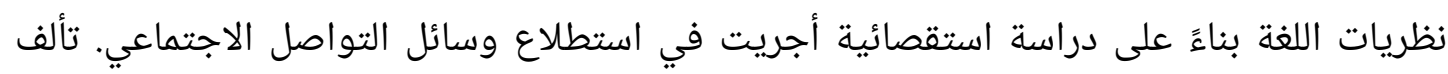
الاستطلاع من سؤالين أساسيين هما: 1- هل أنت على دراية بنظريات اللغة؟ 2- هل درست نظريات اللغة في دراستك الأكاديمية؟ بلغ عدد المعلمين الذين أجابوا عن الأسئلة 63. المعلمون يقومون بالتدريس من القطاعين العام والخاص. أظهرت النتيجة أن 58 من المعلمين لم يكونوا على دراية بنظريات اللغة. علاوة على ذلك ، أكد 60 من المعلمين أنهم لم يدرسوا نظريات اللغة في دراستهم. لذلك اطك ، تهدف هذه الدراسة إلى إدخال النظريات اللغوية بما في ذلك السلوكيات ، والنظرية ، والتفاعلية بالإضافة إلى المبادئ ، ونقاط القوة ونقاط الضعف في كل نظرية. وخلصت الدراسة إلى أنه يتعين على المعلمين التعرف على نظريات اكتساب اللغة من خلال قراءة الكتب وقراءة المقالات والمشاركة في دورات تطوير المعلمين من أجل جعل فصولهم أكثر فعالية وتأثيراً. 